\title{
Feeding by protists and copepods on the heterotrophic dinoflagellates Pfiesteria piscicida, Stoeckeria algicida, and Luciella masanensis
}

\author{
Hae Jin Jeong ${ }^{1, *}$, Jae Seong Kim ${ }^{1}$, Jae Yoon Song ${ }^{2}$, Jong Hyeok Kim ${ }^{3}$, \\ Tae Hoon Kim ${ }^{3}$, Soo Kyeum Kim ${ }^{3}$, Nam Seon Kang ${ }^{1}$
}

${ }^{1}$ School of Earth and Environmental Sciences, College of Natural Sciences, Seoul National University, Seoul 151-747, ROK
${ }^{2}$ Red Tide Research Center, Research Institute of Oceanography, Seoul National University, Seoul 151-747, ROK
${ }^{3}$ Department of Oceanography, College of Ocean Science and Technology, Kunsan National University, Kunsan 573-701, ROK

\begin{abstract}
To investigate interactions between the heterotrophic dinoflagellates Pfiesteria piscicida, Stoeckeria algicida, and Luciella masanensis and their protozoan and metazoan predators, we measured the growth and/or ingestion rates of the heterotrophic dinoflagellate Oxyrrhis marina, the ciliate Strombidinopsis jeokjo, and the calanoid copepods Acartia spp. (A. hongi and A. omorii) when fed on $P$. piscicida, S. algicida, and L. masanensis. The maximum growth and ingestion rates of $O$. marina fed on $P$. piscicida $\left(0.66 \mathrm{~d}^{-1}\right.$ and $0.33 \mathrm{ng} \mathrm{C}$ predator ${ }^{-1} \mathrm{~d}^{-1}$, respectively) were markedly higher than those of the same predator fed on $S$. algicida $\left(0.22 \mathrm{~d}^{-1}\right.$ and $0.14 \mathrm{ng} \mathrm{C}$ predator $\mathrm{d}^{-1}$, respectively) or L. masanensis $\left(0.04 \mathrm{~d}^{-1}\right.$ and $0.07 \mathrm{ng} C$ predator ${ }^{-1} \mathrm{~d}^{-1}$, respectively). The maximum growth and ingestion rates of $S$. jeokjo fed on $P$. piscicida and $S$. algicida (1.61 to $1.77 \mathrm{~d}^{-1}$ and 44 to 49 ng C predator $^{-1} \mathrm{~d}^{-1}$, respectively) were much higher than when fed on L. masanensis $\left(-0.1 \mathrm{~d}^{-1}\right.$ and $10 \mathrm{ng} \mathrm{C}$ predator $^{-1} \mathrm{~d}^{-1}$, respectively). $S$. jeokjo had significantly higher attack ratios (number of attempted captures relative to number of physical contacts between predator and prey) when fed on P. piscicida and S. algicida (18 to $25 \%$ ) than on L. masanensis (5\%). Similarly, successful capture (number of prey ingested relative to number of attempted captures) of $P$. piscicida and $S$. algicida (82 to $87 \%$ ) was significantly higher than that of $L$. masanensis $(2 \%)$. L. masanensis may have defensive behavior or chemical protection against predation. However, maximum ingestion rates of Acartia spp. fed on these dinoflagellate species were similar. In understanding the population dynamics and predatorprey interactions of these 3 closely related dinoflagellate species, it is important to distinguish between predation by protists and by copepods.
\end{abstract}

KEY WORDS: Graze $\cdot$ Growth $\cdot$ Harmful algal bloom $\cdot$ Ingestion $\cdot$ Marine $\cdot$ Protist $\cdot$ Red tide

\section{INTRODUCTION}

Since the small heterotrophic dinoflagellate Pfiesteria piscicida (order Peridiniales and family Pfiesteriaceae) was first discovered in the early 1990s (Steidinger et al. 1996), several more dinoflagellate species in the family Pfiesteriaceae, such as Cryptoperidiniopsis brodyi, Luciella atlantis, L. masanensis, Pseudopfiesteria shumwayae, and Stoeckeria algicida, have been discovered (Jeong et al. 2005b, Litaker et al. 2005, Steidinger et al. 2006, Mason et al. 2007). Both scientists and the public have paid attention to these dinoflagellates because some of the species are harmful to fish (Noga et al. 1996, Glasgow et al. 2001), shellfish (Springer et al. 2002, Shumway et al. 2006), and humans (Schmechel \& Koltai 2001). These dinoflagellates often co-occur in estuaries as well as in coastal waters (e.g. Lewitus et al. 2002). Their cell length and width are approximately 5 to $25 \mu \mathrm{m}$ and 3 to $20 \mu \mathrm{m}$, respectively, and the ranges of the cell lengths and widths overlap between species (Jeong et al. 2006). Further, their shapes are very similar, whereas their plate patterns and DNA sequences clearly differ (Steidinger et al. 1996, Jeong et al. 2005b, 2006, Litaker et 
al. 2005, Rublee et al. 2005, Marshall et al. 2006). Therefore, it is very difficult to distinguish one species from the others in fixed samples. They feed on prey with the same feeding mechanism, i.e. by using a peduncle (a feeding tube) (Burkholder \& Glasgow 1995, Jeong et al. 2005a). An important question arises: do they have similar ecological roles in marine plankton communities? With respect to their ecological roles, their feeding and mortality due to predation are important factors. Recent studies (Jeong et al. 2006, 2007a) have revealed that the kinds of prey species which L. masanensis (previously Lucy) feeds on were very similar to those consumed by $P$. piscicida. However, the kinds of prey species which $P$. piscicida and L. masanensis feed on are very different from those consumed by $S$. algicida, which is known to feed only on the raphidophyte Heterosigma akashiwo and blood cells (Jeong et al. 2005b, 2007a). Also, the growth and ingestion rates of $P$. piscicida feeding on optimal and suboptimal algal prey and fish blood cells were usually higher than those of $L$. masanensis feeding on the same prey species (Jeong et al. 2006, 2007a). Therefore, with regard to feeding, $P$. piscicida, L. masanensis, and $S$. algicida have different roles.

With regard to mortality due to predation, limited studies have thus far reported on the growth and/or ingestion rates of the predators on Pfiesteria piscicida (Mallin et al. 1995, Stoecker et al. 2000, Stoecker \& Gustafson 2002, Gransden \& Lewitus 2003, Setëlë et al. 2005, Lewitus et al. 2006); these predators include the naked ciliates Euplotes spp., Strombidium spp., and Strobilidium sp., the tintinnid ciliates Tintinnopsis spp., Tintinnidium spp., Nolaclusilis spp., Favella spp., rotifers, and the copepod Acartia tonsa (Stoecker et al. 2000, Stoecker \& Gustafson 2002, Gransden \& Lewitus 2003, Lewitus et al. 2006). Moreover, no studies have thus far been conducted on predators that feed on Luciella masanensis and Stoeckeria algicida. Therefore, to investigate the mortality rates due to predation for these 2 dinoflagellates and to investigate whether they play ecological roles similar to $P$. piscicida, we need to measure the numerical (i.e. growth rate) and functional responses (i.e. ingestion rate) of common predators to prey concentration when fed on $P$. piscicida, $S$. algicida, and L. masanensis.

Heterotrophic dinoflagellates, ciliates, and copepods are some of the major components in marine planktonic food webs. Heterotrophic dinoflagellates and ciliates are ubiquitous and occasionally dominate within the microzooplankton in terms of abundance and/or biomass, while copepods dominate similarly within the mesozooplankton (Lessard 1991, Jeong 1999, Kimmel \& Roman 2004, Turner et al. 2005). These 3 groups sometimes have considerable grazing or predation impact on populations of diverse prey (Verity et al. 1999, Kim \& Jeong 2004). Heterotrophic dinoflagellates feed on a variety of prey (for review, see Jeong 1999). Ciliates also feed on diverse prey, including bacteria (e.g. Sherr \& Sherr 2002), algae (Montagnes et al. 1996, Kamiyama \& Arima 2001), and heterotrophic dinoflagellates (Jeong et al. 2004). However, no studies have been conducted on predator-prey relationships among heterotrophic dinoflagellates, and only a few studies have been conducted on predation by ciliates on heterotrophic dinoflagellates (Stoecker et al. 2000, Gransden \& Lewitus 2003, Jeong et al. 2004, Lewitus et al. 2006). The lack of information regarding the interactions among heterotrophic dinoflagellates and between ciliates and heterotrophic dinoflagellates restricts our understanding of the cycling of materials, energy flow, and population dynamics of dominant heterotrophic dinoflagellates in marine food webs. Copepods feed on diverse prey, including algae (e.g. Turner et al. 2005), heterotrophic dinoflagellates, and ciliates (Gifford \& Dagg 1991, Jeong et al. 2001, Roman et al. 2006). However, information available on predation by copepods on heterotrophic dinoflagellates is also much less than that for phototrophic dinoflagellate prey. When Pfiesteria piscicida, Stoeckeria algicida, and Luciella masanensis are offered singularly as prey to heterotrophic dinoflagellates, ciliates, and copepods, these predators may display different patterns in their functional responses to the concentration of each prey species.

To explore differential feeding by heterotrophic dinoflagellates, ciliates, and copepods on heterotrophic dinoflagellates, we established cultures of Pfiesteria piscicida, Stoeckeria algicida, and Luciella masanensis as prey, and the heterotrophic dinoflagellate Oxyrrhis marina, the ciliate Strombidinopsis jeokjo, and the calanoid copepods Acartia spp. (A. hongi and A. omorii) as predators, and conducted experiments to measure the growth and/or ingestion rates of each predator feeding on each prey species. These prey and predators often coexist in Masan Bay and/or the coastal waters off Kunsan, Korea. The results of the present study provide a basis for understanding the interactions between $P$. piscicida, $S$. algicida, and $L$. masanensis and their predators and the ecological roles of these 3 heterotrophic dinoflagellates in marine planktonic communities.

\section{MATERIALS AND METHODS}

Preparation of experimental organisms. For the isolation and culture of Pfiesteria piscicida (GenBank Accession number AM231031), Stoeckeria algicida (AJ841809), and Luciella masanensis (AM050344), 
plankton samples were collected using water samplers from the surface waters off Incheon and Masan Bay, Korea (Table 1). The mixotrophic dinoflagellate Amphidinium carterae or the raphidophyte Heterosigma akashiwo was provided as prey, and a clonal culture of each prey species was established by 2 serial single-cell isolations as described in Jeong et al. (2005a, 2006, 2007a). These prey cultures were maintained at $20^{\circ} \mathrm{C}$ for $>3$ mo before experiments were conducted. The volume of $P$. piscicida, $S$. algicida, and L. masanensis cells $(\mathrm{n}=20$ for each species), collected just before experiments began, was calculated by geometric formula, and the carbon content of $P$. piscicida (0.06 ng C cell ${ }^{-1}$ ), S. algicida (0.08), and L. masanensis (0.06) was estimated from the cell volume according to the method of Menden-Deuer \& Lessard (2000).

For the isolation and culture of the predator Oxyrrhis marina (or Strombidinopsis jeokjo), plankton samples were collected with a $25 \mathrm{~cm}$ diameter, $25 \mu \mathrm{m}$ mesh plankton net (or a $40 \mathrm{~cm}$ diameter, $25 \mu \mathrm{m}$ mesh net) (Table 1). A clonal culture of each protistan predator was established by 2 serial single-cell isolations as described in Jeong et al. $(2003,2004)$. These predator cultures were maintained at $20^{\circ} \mathrm{C}$ for $>1$ mo before experiments were conducted.
Using a $303 \mu \mathrm{m}$ mesh net, copepods were collected from the mouth of the Keum Estuary, Kunsan, Korea, in November 2005 and were then acclimatized in a $20^{\circ} \mathrm{C}$ room in the presence of Prorocentrum minimum for 1 wk (Table 1). Adult female Acartia spp. (A. hongi and A. omorii) were used for these experiments. A. hongi (Soh \& Suh 2000) and A. omorii, which coexist in the coastal waters off western Korea, are similar and it is impossible to distinguish between the 2 species when they are in a viable state.

Growth and ingestion rates. These experiments were designed to measure the growth and/or ingestion rates of Oxyrrhis marina, Strombidinopsis jeokjo, and Acartia spp. as a function of the prey concentration when fed on each of Pfiesteria piscicida, Stoeckeria algicida, and Luciella masanensis (Table 2).

One day before these experiments were conducted, dense cultures of Oxyrrhis marina growing on Amphidinium carterae were transferred into $500 \mathrm{ml}$ polycarbonate (PC) bottles containing 2 different concentrations of the target prey (ca. 50 cells ml$^{-1}$ for 5 lower prey concentrations and ca. 1000 cells ml ${ }^{-1}$ for 4 upper prey concentrations; see Table 2). This was done to minimize possible residual growth resulting from the ingestion of prey during batch culture. The bottles were filled to capacity with freshly filtered seawater,

Table 1. Isolation and maintenance conditions of the experimental organisms

\begin{tabular}{|c|c|c|c|c|c|c|c|}
\hline Organism & Location & Time & $\begin{array}{l}\text { Temp. } \\
\left({ }^{\circ} \mathrm{C}\right)\end{array}$ & $\begin{array}{l}\text { Salinity } \\
\text { (psu) }\end{array}$ & Prey species & $\begin{array}{l}\text { Concentration } \\
\left(\text { cells } \mathrm{ml}^{-1}\right)\end{array}$ & Source \\
\hline Pfiesteria piscicida & Off Incheon & Jul 2005 & 24.0 & 25.4 & Amphidinium carterea & $20000-30000$ & Jeong et al. (2006) \\
\hline Stoeckeria algicida & Masan Bay & Jul 2004 & 24.8 & 20.6 & Heterosigma akashiwo & 30000 & Jeong et al. (2005a) \\
\hline Luciella masanensis & Masan Bay & Apr 2005 & 16.0 & 28.0 & Amphidinium carterea & $30000-40000$ & Jeong et al. (2007a) \\
\hline Oxyrrhis marina & Keum Estuary & May 2001 & 16.0 & 27.7 & Amphidinium carterea & 8000 & Jeong et al. (2003) \\
\hline Strombidinopsis jeokjo & Off Kunsan & Aug 2005 & 25.1 & 27.0 & Prorocentrum micans & 5000 & As in Jeong et al. (2004) \\
\hline Acartia spp. ${ }^{\mathrm{a}}$ & Keum Estuary & Nov 2005 & 12.5 & 24.6 & Prorocentrum mimimum & 10000 & \\
\hline
\end{tabular}

Table 2. Design of experiments

\begin{tabular}{|c|c|c|c|c|}
\hline \multirow[t]{2}{*}{ Expt } & \multirow{2}{*}{\multicolumn{2}{|c|}{$\begin{array}{ll}\text { Species } & \text { Prey } \\
\end{array}$}} & \multirow{2}{*}{ Species } & \multirow[b]{2}{*}{$\begin{array}{l}\text { Density } \\
\left(\text { cells } \mathrm{ml}^{-1}\right)^{\mathrm{a}, \mathrm{b}}\end{array}$} \\
\hline & & & & \\
\hline 1 & Pfiesteria piscicida & $0,36,153,298,530,1170,3500,8260,15370$ & Oxyrrhis marina & $9-361(363)$ \\
\hline 2 & Stoeckeria algicida & $0,48,190,428,976,2970,4589,10510,15940$ & Oxyrrhis marina & $9-490(493)$ \\
\hline 3 & Luciella masanensis & $0,57,104,210,477,1170,3080,9820,15260$ & Oxyrrhis marina & $14-452(452)$ \\
\hline 4 & Pfiesteria piscicida & $0,42,65,162,388,924,1570,4130,8200,15090$ & Strombidinopsis jeokjo & $3.5-8.3(6.9)$ \\
\hline 5 & Stoeckeria algicida & $0,40,85,170,488,846,1760,3650,6020,11640$ & Strombidinopsis jeokjo & $2.8-7.5(6.6)$ \\
\hline 6 & Luciella masanensis & $0,61,100,242,478,1050,2160,5410,10680,17420$ & Strombidinopsis jeokjo & $4.4-12.7(9.2)$ \\
\hline 7 & Pfiesteria piscicida & $39,67,239,775,2570,8560,21790$ & Acartia spp. ${ }^{\mathrm{c}}$ & 20 \\
\hline 8 & Stoeckeria algicida & $95,416,965,2940,5350,8140,14460$ & Acartia spp. & 20 \\
\hline 9 & Luciella masanensis & $49,95,266,1020,2980,10870,27810$ & Acartia spp. & 20 \\
\hline
\end{tabular}


capped, and placed on plankton wheels rotating at $0.9 \mathrm{rpm}$ and incubated at $20^{\circ} \mathrm{C}$ under the illumination of $20 \mu E \mathrm{~m}^{-2} \mathrm{~s}^{-1}$ on a $14 \mathrm{~h}$ light:10 h dark cycle. To monitor the conditions and interaction between predator and prey species, the cultures were periodically removed from the rotating wheels, observed through the surface of the capped bottles with a dissecting microscope, and then returned to the rotating wheels. Once the target prey cells were no longer detectable, three $1 \mathrm{ml}$ aliquots from each bottle were counted using a compound microscope to determine the cell concentrations of $O$. marina, and the cultures were then used to conduct experiments.

For each experiment, the initial concentrations of Oxyrrhis marina and a target prey species (each of Pfiesteria piscicida, Stoeckeria algicida, and Luciella masanensis) were established using an autopipette to deliver predetermined volumes of known cell concentrations to the bottles. Triplicate $42 \mathrm{ml}$ PC experiment bottles (mixtures of predator and prey) and triplicate control bottles (prey only) were set up at each predator-prey combination. Triplicate control bottles containing only $O$. marina were also established at 1 predator concentration. To obtain similar water conditions, the water of a predator culture was filtered through a $0.7 \mu \mathrm{m} \mathrm{GF/F} \mathrm{filter} \mathrm{(Whatman)} \mathrm{and} \mathrm{then}$ added to the prey control bottles in the same amount as the volume of the predator culture added into the experiment bottles for each predator-prey combination. All the bottles were then filled to capacity with freshly filtered seawater and capped. To determine the actual predator and prey densities at the beginning of the experiment, a $5 \mathrm{ml}$ aliquot was removed from each bottle, fixed with 5\% Lugol's solution, and examined with a compound microscope to determine predator and prey abundance by enumerating the cells in three $1 \mathrm{ml}$ Sedgwick-Rafter chambers (SRCs). The bottles were refilled to capacity with freshly filtered seawater, capped, and placed on rotating wheels under the conditions described above. Dilution of the cultures associated with refilling the bottles was considered in calculating growth and ingestion rates. A $10 \mathrm{ml}$ aliquot was taken from each bottle at $48 \mathrm{~h}$ and fixed with $5 \%$ Lugol's solution, and the abundances of $O$. marina and the target prey were determined by counting all or $>300$ cells in three $1 \mathrm{ml}$ SRCs. Prior to taking subsamples, the condition of $O$. marina and its prey was assessed using a dissecting microscope as described above.

One day before these experiments were conducted, dense cultures of Strombidinopsis jeokjo growing on Prorocentrum micans were transferred into a $500 \mathrm{ml}$ PC bottle containing 2 concentrations of the target prey $\left(50\right.$ cells $\mathrm{ml}^{-1}$ for 6 lower prey concentration and 1000 cells $\mathrm{ml}^{-1}$ for 4 upper prey concentration; see
Table 2). The bottle was filled to capacity with filtered seawater and placed on a rotating wheel for incubation as described above. When the prey cells were undetectable, the abundance of $S$. jeokjo was determined by enumerating cells in three $1 \mathrm{ml}$ SRCs.

The initial concentrations of Strombidinopsis jeokjo and the target prey were established using an autopipette. Triplicate $42 \mathrm{ml}$ PC experiment bottles and triplicate control bottles (prey only) for each predator-prey combination and triplicate control bottles containing only $S$. jeokjo at 1 predator concentration were also established as described above. To determine actual predator and prey concentrations at the beginning of the experiment, a $5 \mathrm{ml}$ aliquot was removed from each bottle and, after $24 \mathrm{~h}$ of incubation, a $10 \mathrm{ml}$ aliquot was removed and fixed with $5 \%$ Lugol's solution; all predator cells and all or $>200$ prey cells in three to five $1 \mathrm{ml}$ SRCs were enumerated. The bottles were refilled to capacity with freshly filtered seawater, capped, and placed on rotating wheels under the environmental conditions described above.

The specific growth rate of Oxyrrhis marina (or Strombidinopsis jeokjo), $\mu\left(\mathrm{d}^{-1}\right)$, was calculated as:

$$
\mu(\mathrm{d})=\left[\ln \left(P_{t} / P_{0}\right)\right] / t
$$

where $P_{0}$ and $P_{t}$ are the concentration of $O$. marina (or $S$. jeokjo) at $0 \mathrm{~h}$ and $48 \mathrm{~h}$ (or $24 \mathrm{~h}$ for $S$. jeokjo), respectively.

Data for Oxyrrhis marina (or Strombidinopsis jeokjo) growth rates were fitted to a Michaelis-Menten equation:

$$
\mu=\frac{\mu_{\max }\left(x-x^{\prime}\right)}{K_{\mathrm{GR}}+\left(x-x^{\prime}\right)}
$$

where $\mu_{\max }$ is the maximum growth rate $\mathrm{d}^{-1}, x$ is prey concentration (cells ml-1 or ng $\mathrm{C} \mathrm{ml}^{-1}$ ), $\mathrm{x}^{\prime}$ is threshold prey concentration (the prey concentration where $\mu=$ $0)$, and $K_{\mathrm{GR}}$ is the prey concentration sustaining $0.5 \mu_{\text {max }}$. Data were iteratively fitted to the model using DeltaGraph ${ }^{\circledR}$ (Delta Point).

Ingestion and clearance rates were calculated using the equations of Frost (1972) and Heinbokel (1978). The incubation time was the same as that for estimating the growth rate. Ingestion rate data for Oxyrrhis marina (or Strombidinopsis jeokjo) were fitted to a Michaelis-Menten equation:

$$
\mathrm{IR}=\frac{I_{\max }(x)}{K_{\mathrm{IR}}+(x)}
$$

where $I_{\text {max }}$ is the maximum ingestion rate (cells predator $^{-1} \mathrm{~d}^{-1}$ or ng $\mathrm{C}$ predator $\left.{ }^{-1} \mathrm{~d}^{-1}\right), \mathrm{x}$ is prey concentration (cells $\mathrm{ml}^{-1}$ or $\mathrm{ng} \mathrm{C} \mathrm{ml} \mathrm{C}^{-1}$ ), and $K_{\mathrm{IR}}$ is the prey concentration sustaining $0.5 I_{\text {max }}$.

For the experiment on the feeding by copepods, initial concentrations of the target prey were established 
using an autopipette, and those of Acartia spp. were obtained by individually transferring the copepods using a Pasteur pipette (Table 2). Triplicate $500 \mathrm{ml} \mathrm{PC}$ experiment bottles and triplicate control bottles (prey only) were set up at each predator-prey combination. To determine actual prey densities at the beginning of the experiment, a $20 \mathrm{ml}$ aliquot was removed from each bottle, fixed with $5 \%$ Lugol's solution, and examined with a compound microscope to determine prey abundance by enumerating cells in three $1 \mathrm{ml}$ SRCs. The bottles were filled again to capacity with freshly filtered seawater, capped, and placed on rotating plankton wheels and incubated at $20^{\circ} \mathrm{C}$ as described above.

After $48 \mathrm{~h}$ of incubation, $20 \mathrm{ml}$ aliquots were taken from each bottle and fixed with 5\% Lugol's solution, and the abundance of the target prey was determined by counting all or $>300$ cells in three $1 \mathrm{ml}$ SRCs. After incubation for 48 h, Acartia spp. were counted. Mortality of Acartia spp. was zero at the end of the incubation. Ingestion and clearance rates were calculated using the equations of Frost (1972) as described above.

Attack ratio and successful capture. This experiment was designed to investigate why the growth and ingestion rates of Strombidinopsis jeokjo feeding on Luciella masanensis were much lower than those achieved on a diet of Pfiesteria piscicida or Stoeckeria algicida.

In this experiment the attack ratio (i.e. the number of attempted captures relative to the number of physical contacts between predator and prey) and successful capture ratio (i.e. the number of prey ingested relative to the number of attempted captures) were determined by monitoring the behavior of Strombidinopsis jeokjo in the presence of Pfiesteria piscicida, Stoeckeria algicida, or Luciella masanensis. Attempted captures represented generation of feeding current by undulating cilia. Successful captures were attacks that resulted in the prey being ingested. Additionally, to explore possible adverse effects (i.e. chemical effects) of the extract of L. masanensis, the water of an L. masanensis culture (density = ca. 20000 cells $^{-1}$ ) was filtered through a $0.7 \mu \mathrm{m}$ GF/F filter and then added into bottles containing the optimal prey species, $P$. piscicida.

Individual Strombidinopsis jeokjo cells starved for $1 \mathrm{~d}$ were transferred to a Petri dish (50 $\mathrm{mm}$ in diameter) containing each prey species (Pfiesteria piscicida, Stoeckeria algicida, and Luciella masanensis) and then each predator was tracked under a dissecting microscope until it successfully engulfed a prey cell or until ca. 10 min had elapsed. For each prey species, the number of predator-prey encounters, attempted prey captures, and ingestion of prey were recorded for 10 to 20 S. jeokjo cells (i.e. 10 to 20 replicates).

\section{RESULTS}

\section{Growth rates}

Oxyrrhis marina grew well feeding on Pfiesteria piscicida and Stoeckeria algicida, but failed to grow when fed Luciella masanensis (Fig. 1). The specific growth rates of $O$. marina consuming $P$. piscicida and $S$. algicida increased rapidly with increasing mean prey concentration (ca. 30 to $60 \mathrm{ng} \mathrm{C} \mathrm{m}{ }^{-1}$ ) but increased only slightly at higher concentrations (Fig. 1A,B). When the
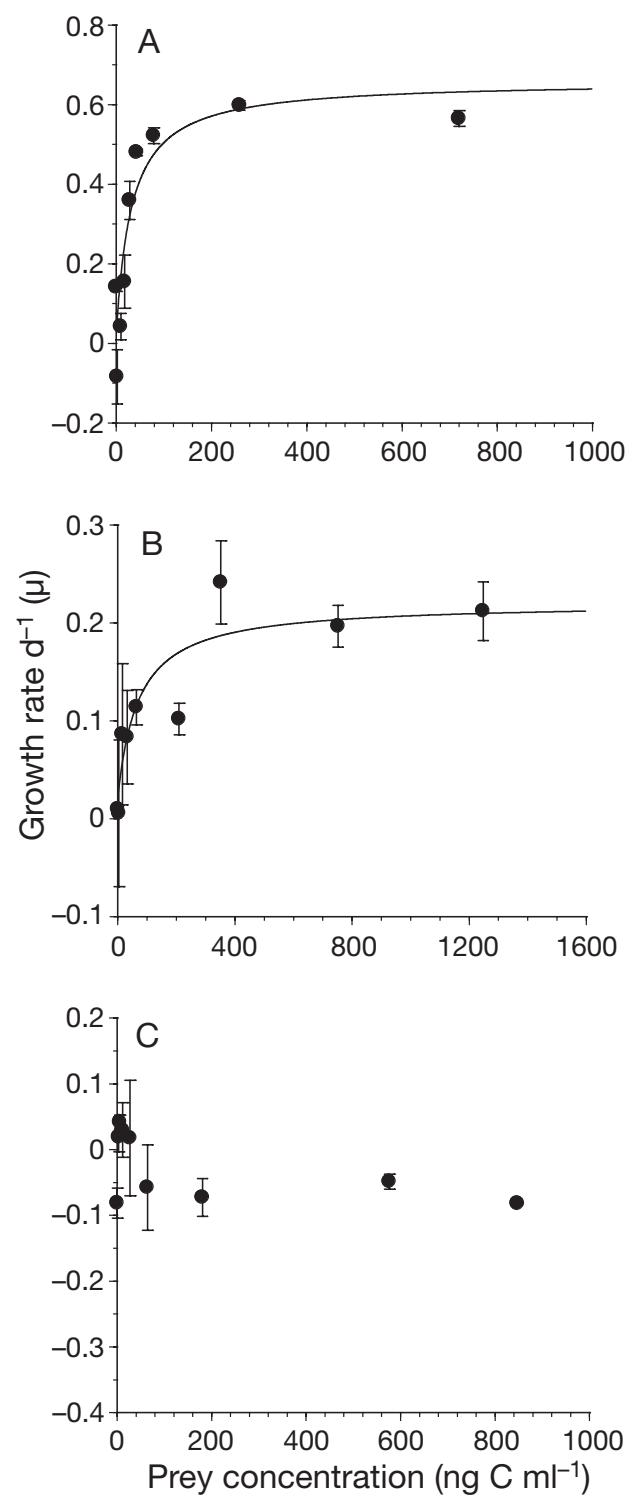

Fig. 1. Mean ( $\pm 1 \mathrm{SE}$ ) specific growth rates of Oxyrrhis marina feeding on (A) Pfiesteria piscicida, (B) Stoeckeria algicida, and (C) Luciella masanensis as a function of mean prey concentration $(x)$. The curves are fitted by a Michaelis-Menten equation (Eq. 2) using all treatments in the experiment; (A) $\mu=0.66([x-0.4] /[21+(x-0.4)]), r^{2}=0.797$. (B) $\mu=0.22$ $([x+5] /[64+(x+5)]), \mathrm{r}^{2}=0.528$ 
data were fitted to Eq. (2), the maximum specific growth rate $\left(\mu_{\max }\right)$ of $O$. marina consuming $P$. piscicida $\left(0.66 \mathrm{~d}^{-1}\right)$ was 3 times higher than when fed $S$. algicida $\left(0.22 \mathrm{~d}^{-1}\right)$ (Table 3$)$. The specific growth rates of $O$. marina consuming $L$. masanensis were between -0.08 and $0.04 \mathrm{~d}^{-1}$ (Fig. 1C).

Like the Oxyrrhis marina predator, Strombidinopsis jeokjo also grew well with Pfiesteria piscicida and Stoeckeria algicida as prey, but failed to grow when consuming Luciella masanensis (Fig. 2A-C). The specific growth rates of $S$. jeokjo when fed $P$. piscicida and $S$. algicida increased rapidly with increasing mean prey concentration (up to ca. $50 \mathrm{ng} \mathrm{C} \mathrm{ml} \mathrm{Cl}^{-1}$ ) but increased only slightly at higher concentrations (Fig. 2A,B). Unlike the O. marina predator, when the data were fitted to Eq. (2), $\mu_{\max }$ of $S$. jeokjo consuming $P$. piscicida $\left(1.77 \mathrm{~d}^{-1}\right)$ was slightly higher than when fed $S$. algicida $\left(1.61 \mathrm{~d}^{-1}\right)$. The specific growth rates of $S$. jeokjo feeding on L. masanensis were between -0.83 and $-0.11 \mathrm{~d}^{-1}$ (Fig. 2C).

\section{Ingestion and clearance rates}

The ingestion rates of Oxyrrhis marina feeding on Pfiesteria piscicida and Stoeckeria algicida increased rapidly with increasing mean prey concentration < ca. 210 to $260 \mathrm{ng} \mathrm{C} \mathrm{ml}^{-1}$, but were saturated at higher concentrations (Fig. 3A,B), while rates when feeding on Luciella masanensis increased rapidly with increasing mean prey concentration (up to ca. $65 \mathrm{ng} \mathrm{C} \mathrm{ml}^{-1}$ ) but increased slowly at higher concentrations (Fig. 3C). When the data were fitted to Eq. (3), the maximum ingestion rate $\left(I_{\max }\right)$ of $O$. marina consuming $P$. piscicida (0.33 ng $\mathrm{C}$ predator ${ }^{-1} \mathrm{~d}^{-1}$ ) was considerably higher than when consuming $S$. algicida (0.14 ng C predator $^{-1}$ $\mathrm{d}^{-1}$ ) and much higher than with $L$. masanensis as prey (0.07 ng $C$ predator ${ }^{-1} \mathrm{~d}^{-1}$ ) (Table 3 ). The maximum clearance rates of $O$. marina feeding on $P$. piscicida and $S$. algicida ( 0.34 to $0.61 \mu$ predator ${ }^{-1} \mathrm{~h}^{-1}$ ) were also much higher than that with $L$. masanensis as prey $\left(0.02 \mu\right.$ predator $\left.{ }^{-1} \mathrm{~h}^{-1}\right)$.

The ingestion rates of Strombidinopsis jeokjo feeding on Pfiesteria piscicida and Stoeckeria algicida increased rapidly with increasing mean prey concentration (ca. 40 to $50 \mathrm{ng} \mathrm{C} \mathrm{ml}{ }^{-1}$ ) but increased slowly at higher concentrations (Fig. 4A,B). The ingestion rates of $S$. jeokjo consuming Luciella masanensis increased with increasing mean prey concentration (up to ca. $270 \mathrm{ng} \mathrm{C} \mathrm{ml}^{-1}$ ) but decreased at higher concentrations (Fig. 4C). When the data were fitted to Eq. (3), I $I_{\max }$ values of $S$. jeokjo consuming $P$. piscicida and $S$. algicida (44 to $49 \mathrm{ng} C$ predator ${ }^{-1} \mathrm{~d}^{-1}$ ) were markedly higher than when feeding on $L$. masanensis (10 ng $C$ predator $\left.^{-1} \mathrm{~d}^{-1}\right)$. The maximum clearance rate of $S$. jeokjo consuming $P$. piscicida (15.4 $\mu$ l predator ${ }^{-1} \mathrm{~h}^{-1}$ ) was higher than those with $S$. algicida and L. masanensis as prey (5.4 to $6.6 \mu$ l predator ${ }^{-1} \mathrm{~h}^{-1}$ ).

The ingestion rate of Acartia spp. feeding on Pfiesteria piscicida and Luciella masanensis increased continuously with increasing mean prey concentration (up to $1300 \mathrm{ng} \mathrm{C} \mathrm{ml}^{-1}$ ) while that resulting from ingestion of Stoeckeria algicida increased with increasing mean prey concentration (up to ca. $650 \mathrm{ng} \mathrm{C} \mathrm{ml} \mathrm{Cl}^{-1}$ ) but was saturated at the highest concentration (Fig. 5). The highest values among the ingestion rates of Acartia spp. feeding on P. piscicida, S. algicida, and L. masanensis were 3850,3640 , and $3490 \mathrm{ng} \mathrm{C}$ predator $^{-1} \mathrm{~d}^{-1}$, respectively, at mean prey concentrations of 1050, 650, and $1330 \mathrm{ng} \mathrm{C} \mathrm{ml}^{-1}$, respectively. The maximum clear-

Table 3. Growth and grazing data for Oxyrrhis marina, Strombidinopsis jeokjo, and Acartia spp. (A. hongi and A. omorii). Parameters are for numerical and/or functional response from Eqs. (2) \& (3) as presented in Figs. 1-4. $\mu_{\max }$ (maximum growth rate, $\mathrm{d}^{-1}$ ), $K_{\mathrm{GR}}$ (prey concentration sustaining $0.5 \mu_{\max }, \mathrm{ng} \mathrm{C} \mathrm{ml}^{-1}$ ), $\mathrm{x}^{\prime}$ (threshold prey concentration, $\mathrm{ng} \mathrm{C}$ ml ${ }^{-1}$ ), $I_{\max }$ (maximum ingestion rate, ng $\mathrm{C}$ predator ${ }^{-1} \mathrm{~d}^{-1}$ ), $K_{\mathrm{IR}}$ (prey concentration sustaining $0.5 I_{\max }, \mathrm{ng} \mathrm{C} \mathrm{ml}^{-1}$ ), $C_{\max }$ (maximum clearance rate, $\mu l$ predator ${ }^{-1} \mathrm{~d}^{-1}$ )

\begin{tabular}{|c|c|c|c|c|c|c|c|c|c|}
\hline Figs. & Species & $\mu_{\max }$ & $K_{\mathrm{GR}}$ & $x^{\prime}$ & $\mathrm{r}^{2}$ & $I_{\max }$ & $K_{\mathrm{IR}}$ & $\mathrm{r}^{2}$ & $C_{\max }$ \\
\hline \multicolumn{10}{|c|}{ Oxyrrhis marina } \\
\hline $1 \mathrm{~A} \& 3 \mathrm{~A}$ & Pfiesteria piscicida & 0.657 & 21 & 0.4 & 0.797 & 0.334 & 83 & 0.876 & 0.34 \\
\hline $1 \mathrm{~B} \& 3 \mathrm{~B}$ & Stoeckeria algicida & 0.220 & 64 & -4.7 & 0.528 & 0.138 & 89 & 0.359 & 0.61 \\
\hline $1 C \& 3 C$ & Luciella masanensis & $0.042^{\mathrm{a}}$ & & & & 0.065 & 132 & 0.335 & 0.01 \\
\hline \multicolumn{10}{|c|}{ Strombidinopsis jeokjo } \\
\hline $2 \mathrm{~A} \& 4 \mathrm{~A}$ & Pfiesteria piscicida & 1.77 & 90 & 23 & 0.783 & 43.5 & 92 & 0.973 & 15.4 \\
\hline $2 B \& 4 B$ & Stoeckeria algicida & 1.61 & 36 & 16 & 0.847 & 49.3 & 187 & 0.955 & 6.6 \\
\hline $2 \mathrm{C} \& 4 \mathrm{C}$ & Luciella masanensis & $-0.11^{\mathrm{a}}$ & & & & $9.8^{\mathrm{a}}$ & & & 5.4 \\
\hline \multicolumn{10}{|c|}{ Acartia spp. } \\
\hline $5 \mathrm{~A}$ & Pfiesteria piscicida & & & & & $3850^{\mathrm{a}}$ & & & 153 \\
\hline $5 \mathrm{~B}$ & Stoeckeria algicida & & & & & $3640^{\mathrm{a}}$ & & & 782 \\
\hline $5 \mathrm{C}$ & Luciella masanensis & & & & & $3490^{\mathrm{a}}$ & & & 432 \\
\hline
\end{tabular}



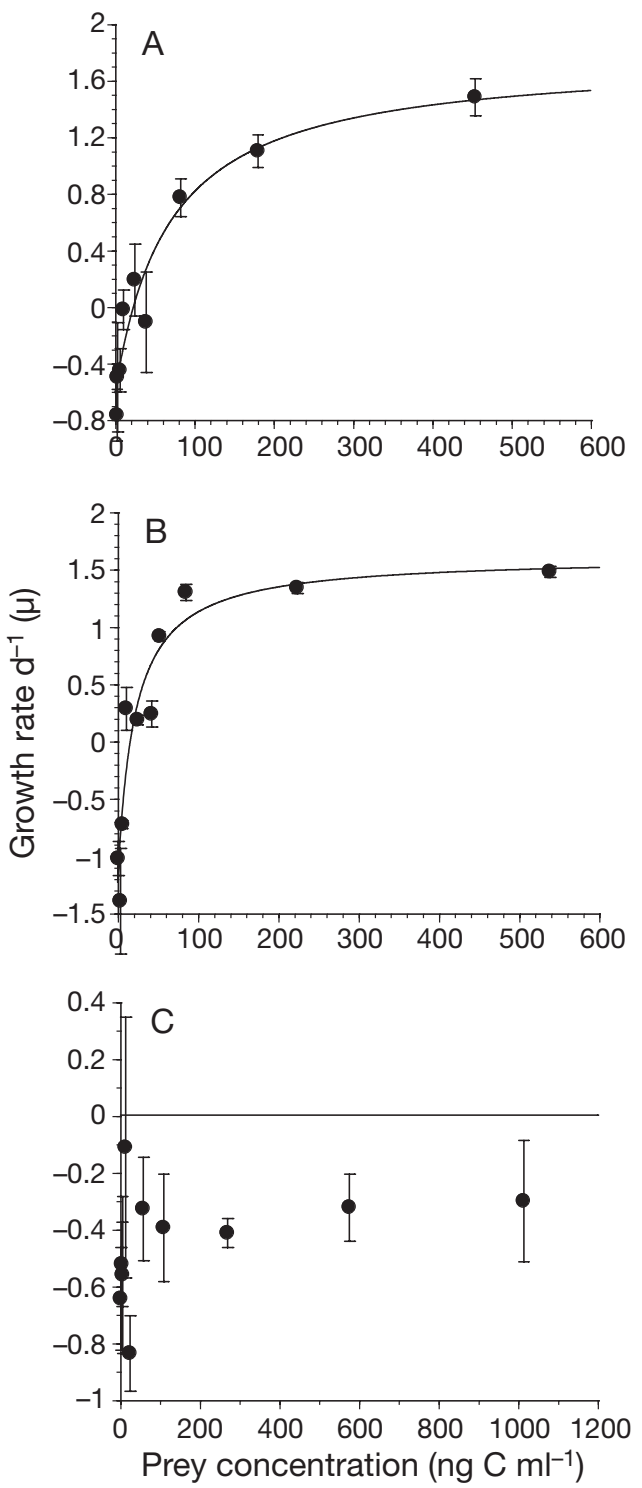

Fig. 2. Mean $( \pm 1 \mathrm{SE})$ specific growth rates of Strombidinopsis jeokjo feeding on (A) Pfiesteria piscicida, (B) Stoeckeria algicida, and (C) Luciella masanensis as a function of mean prey concentration $(x)$. The curves are fitted by a MichaelisMenten equation (Eq. 2) using all treatments in the experiment; (A) $\mu=1.77([x-23] /[90+(x-23)]), r^{2}=0.783$. (B) $\mu=1.61([x-16] /[36+(x-16)]), r^{2}=0.847$

ance rates of Acartia spp. feeding on $P$. piscicida, $S$. algicida, and L. masanensis were 153, 782, and $432 \mu \mathrm{l}$ predator ${ }^{-1} \mathrm{~h}^{-1}$, respectively.

\section{Attack ratio and successful capture}

Strombidinopsis jeokjo had a significantly higher attack ratio, (number of attempted captures)/(number of physical contacts), when feeding on Pfiesteria pisci-
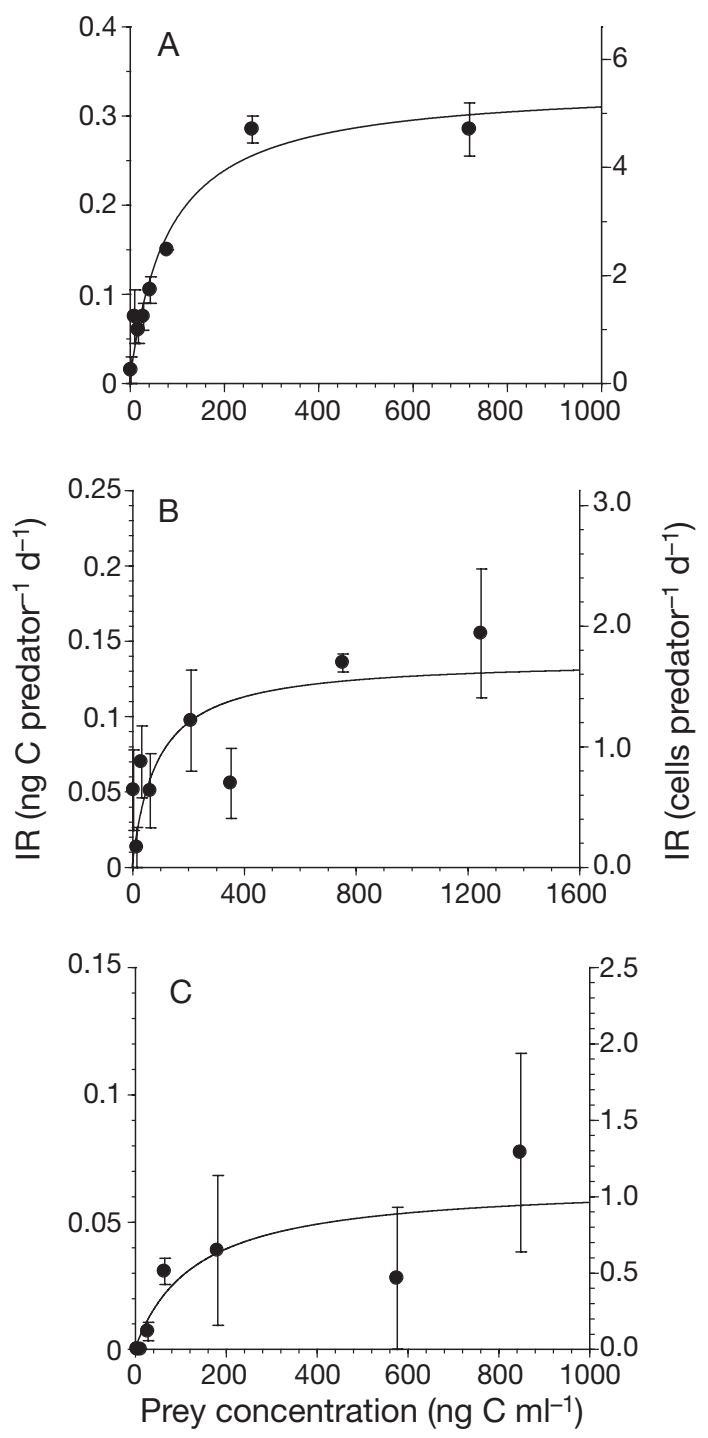

Fig. 3. Mean ( $\pm 1 \mathrm{SE}$ ) ingestion rates (IR) of Oxyrrhis marina feeding on (A) Pfiesteria piscicida, (B) Stoeckeria algicida, and (C) Luciella masanensis as a function of mean prey concentration $(x)$. The curves are fitted by a Michaelis-Menten equation (Eq. 3) using all treatments in the experiment; (A) IR, ng C predator ${ }^{-1} \mathrm{~d}^{-1}=0.33(\mathrm{x} /[83+\mathrm{x}]), \mathrm{r}^{2}=0.876$. (B) IR, ng C predator $^{-1} \mathrm{~d}^{-1}=0.14(\mathrm{x} /[89+\mathrm{x}]), \mathrm{r}^{2}=0.359$. (C) IR, ng C predator $^{-1} \mathrm{~d}^{-1}=0.07(x /[132+x]), \mathrm{r}^{2}=0.335$

cida (mean $\pm \mathrm{SE}=25 \pm 5 \%$ ) than when consuming Luciella masanensis ( $5 \pm 1 \%$ ) (1-tailed t-test, $\mathrm{p}<0.005)$, but not significantly higher than with Stoeckeria algicida as prey(18 $\pm 3 \%)(p>0.1)$ (Fig. 6A). S. jeokjo also had a significantly higher attack ratio when feeding on $P$. piscicida without added filtered water of a $L$. masanensis culture than with added filtered water $(9 \pm 3 \%)$ (1-tailed t-test, $\mathrm{p}<0.05)$.

Similarly, Strombidinopsis jeokjo had a significantly higher successful capture ratio, (number of prey 

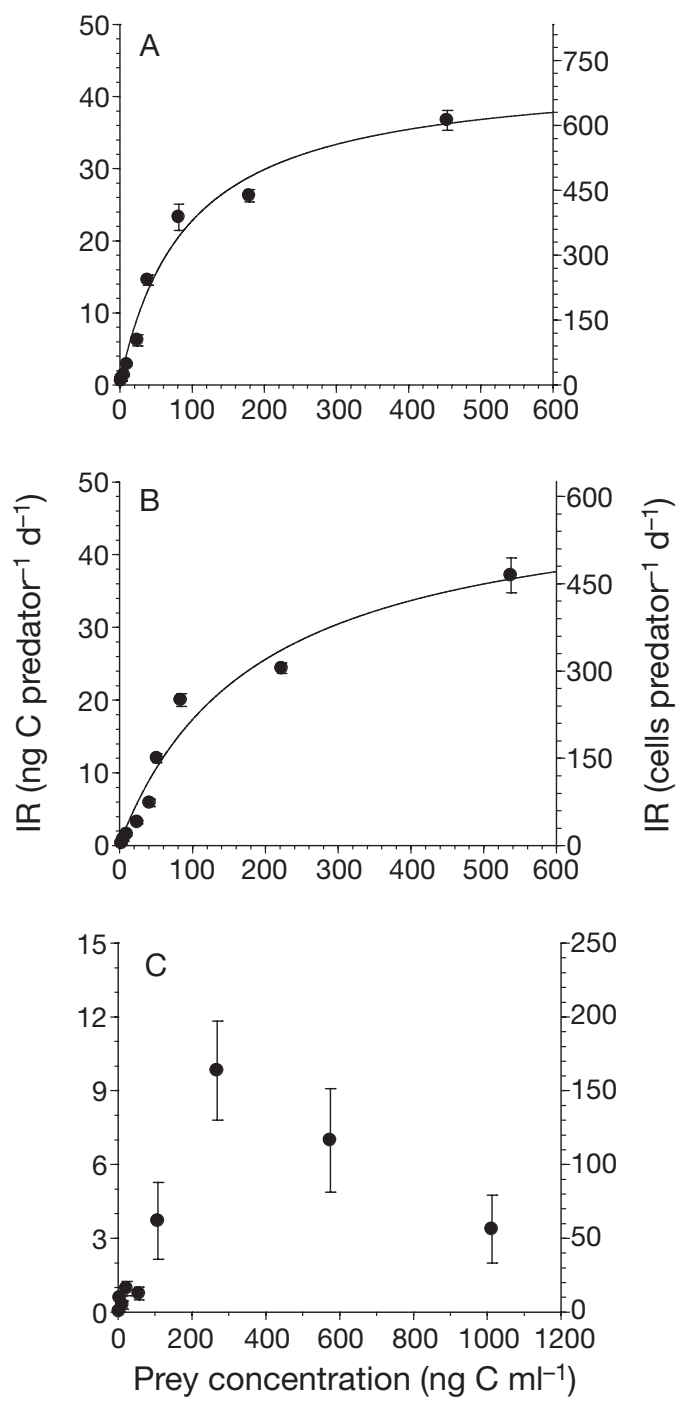

Fig. 4. Mean ( $\pm 1 \mathrm{SE}$ ) ingestion rates (IR) of Strombidinopsis jeokjo feeding on (A) Pfiesteria piscicida, (B) Stoeckeria algicida, and (C) Luciella masanensis as a function of mean prey concentration $(x)$. The curves are fitted by a MichaelisMenten equation (Eq. 3) using all treatments in the experiment; (A) IR, ng C predator ${ }^{-1} \mathrm{~d}^{-1}=44(x /[92+x]), \mathrm{r}^{2}=0.973$. (B) IR, ng C predator ${ }^{-1} \mathrm{~d}^{-1}=49(\mathrm{x} /[187+\mathrm{x}]), \mathrm{r}^{2}=0.955$

ingested)/(number of attempted captures), when feeding on Pfiesteria piscicida (mean $\pm \mathrm{SE}=82 \pm 6 \%$ ) than when consuming Luciella masanensis $(2 \pm 2 \%)$ (1tailed t-test, $\mathrm{p}<0.005)$; however, the former ratio was not significantly lower than that for $S$. jeokjo feeding on Stoeckeria algicida (87 $\pm 5 \%$ ) (p > 0.1) (Fig. 6B). $S$. jeokjo also had a significantly higher successful capture ratio when feeding on $P$. piscicida without added filtered water of a L. masanensis culture than with added filtered water $(49 \pm 5 \%)$ (1-tailed t-test, $\mathrm{p}<$ 0.01). In the case of unsuccessful captures, $S$. jeokjo rejected the prey cells delivered to the mouth area.
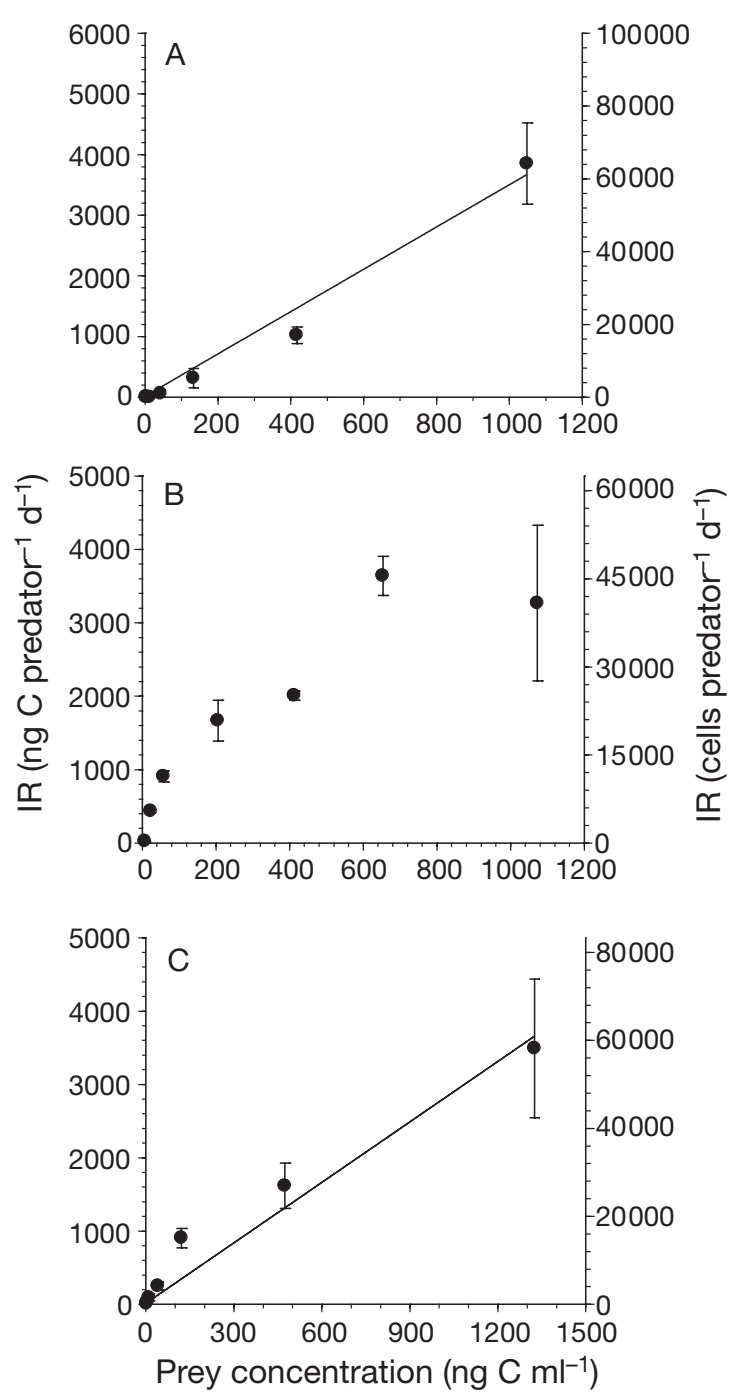

Fig. 5. Mean ( $\pm 1 \mathrm{SE}$ ) ingestion rates (IR) of Acartia spp. (A. hongi and A. omorii) feeding on (A) Pfiesteria piscicida, (B) Stoeckeria algicida, and (C) Luciella masanensis as a function of mean prey concentration $(x)$. The curves are fitted by the equation of the linear regression $(\mathrm{A}, \mathrm{C})$ and a MichaelisMenten equation (B) using all treatments in the experiment; (A) IR, ng C predator ${ }^{-1} \mathrm{~d}^{-1}=3.49(x), \mathrm{r}^{2}=0.905$. (B) IR, ng C predator $^{-1} \mathrm{~d}^{-1}=3070(\mathrm{x} /[140+\mathrm{x}]), \mathrm{r}^{2}=0.754$. (C) IR, ng C predator $^{-1} \mathrm{~d}^{-1}=2.75(x), \mathrm{r}^{2}=0.787$

\section{DISCUSSION}

\section{Differential feeding}

The present study reveals that despite the fact that Pfiesteria piscicida, Stoeckeria algicida, and Luciella masanensis belonging to the family Pfiesteriaceae have similar sizes and shapes, they caused different functional responses by Oxyrrhis marina and Strombidinopsis jeokjo. In particular, while $P$. piscicida and 

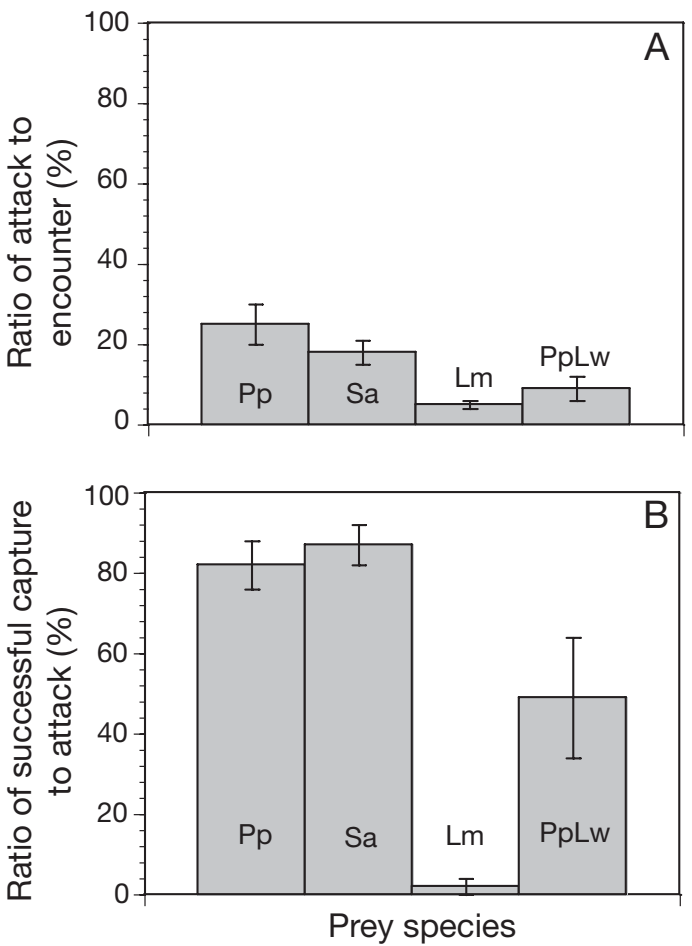

Fig. 6. Mean ( $\pm 1 \mathrm{SE}$ ) ratios of (A) attack by Strombidinopsis jeokjo feeding on Pfiesteria piscicida (Pp), Stoeckeria algicida (Sa), Luciella masanensis (Lm), and Pfiesteria piscicida with added filtered water of a L. masanensis culture (PpLw) relative to encounter and of (B) successful capture relative to attack. Values are treatment means $\pm 1 \mathrm{SE}$

$S$. algicida did support positive growth of the protist predators $O$. marina and $S$. jeokjo, L. masanensis did not. $I_{\max }$ of $S$. jeokjo feeding on $P$. piscicida or $S$. algicida was substantially higher than when fed L. masanensis.

Several possible explanations exist for these prey dependent differences in ingestion rate and growth rate of Strombidinopsis jeokjo. (1) L. masanensis may be less attractive to $S$. jeokjo as prey compared to $P$. piscicida and $S$. algicida. $S$. jeokjo has much lower attack ratios when fed on $L$. masanensis than when fed on P. piscicida and S. algicida. Also, S. jeokjo had significantly higher attack and successful capture ratios when fed on $P$. piscicida without added filtered water of an L. masanensis culture than with added filtered water. This suggests that chemicals excreted from $L$. masanensis may inhibit feeding by $S$. jeokjo. Recently, Moeller et al. (2007) reported the nature of toxins produced by $P$. piscicida (i.e. metal complexes and free radical toxins) by using 5 different analytical methods. L. masanensis may have toxins that are more potent than those of $P$. piscicida; however, the presence and toxicity of the toxins of L. masanensis should be investigated in future studies. (2) $S$. jeokjo may have more difficulty in handling $L$. masanensis than P. piscicida and $S$. algicida. S. jeokjo has much lower successful capture ratios when fed on the former dinoflagellate prey than when fed on the latter dinoflagellate prey. (3) Some L. masanensis cells were observed to attack $S$. jeokjo, while no $P$. piscicida or $S$. algicida cells attacked their predators. This attack may be partially responsible for the decrease in the ingestion rate of $L$. masanensis by $S$. jeokjo at mean prey concentrations $>270 \mathrm{ng} \mathrm{C} \mathrm{ml}^{-1}$ and indicates direct reversal of predator-prey relationships among heterotrophic protists. Only a few other reports have indicated the same; the heterotrophic dinoflagellate Protoperidinium divergens and the mixotrophic dinoflagellate Fragilidium cf. mexicanum were able to feed on each other (Jeong et al. 1997).

To understand the population dynamics of Pfiesteria piscicida, Stoeckeria algicida, and Luciella masanensis, data on the prey species, their growth rates $(k)$ and mortality rates due to predation $(g)$ should be obtained. $P$. piscicida and L. masanensis feed on diverse prey species and have several optimal and suboptimal prey species that support their high growth rates, such as fish blood cells, Amphidinium carterae, cryptophytes, and Heterosigma akashiwo (0.8 to $1.8 \mathrm{~d}^{-1}$ ) (Burkholder \& Glasgow 1995, 1997, Parrow et al. 2002, Seaborn et al. 2002, Lin et al. 2004, Jeong et al. 2005b, 2006, 2007a). However, $S$. algicida feeds only on $H$. akashiwo and blood cells (Jeong et al. 2005a, 2007a). When combining the kind of prey species, growth rates, and mortality rates due to predation, L. masanensis (with many prey species, high $k$ and low $g$ ) is the most competitive, followed by $P$. piscicida (with many prey species, high $k$ and high $g$ ), and finally $S$. algicida (with a few prey species, high $k$ on a few prey species but zero or low $k$ on many other co-occurring plankton, and high $g$ ) and the least competitive. $L$. masanensis is likely to dominate the assemblage of $P$. piscicida, S. algicida, and L. masanensis when protistan predators are abundant. Gransden \& Lewitus (2003) reported that the growth rate of $P$. piscicida feeding on the cryptophyte Storeatula major was significantly higher than that of Cryptoperidiniopsis sp. and suggested that the euplotid ciliate Euplotes woodruffi had a greater ability to control the population growth of $P$. piscicida than Cryptoperidiniopsis sp. Therefore, $P$. piscicida, $S$. algicida, L. masanensis, and Cryptoperidiniopsis sp. have different ecological niches in marine planktonic food webs.

The results of the present study suggest that the predator with the lowest $I_{\max }$ (Oxyrrhis marina) has a clearly different $I_{\max }$ on these 3 different prey species (specialist), while the predators with the highest $I_{\max }$ (Acartia spp.) have relatively similar $I_{\max }$ values on these 3 different prey species (generalists). And the predator with a moderate $I_{\max }$ (Strombidinopsis jeokjo) 
shows a combination of specialist and generalist. The smallest predator $O$. marina may detect differences in taste, nutrition, and/or behavior of these 3 different prey species, but the largest predator Acartia spp. may not detect such differences. Feeding by some copepods is affected by some toxic mixotrophic dinoflagellates (e.g. Huntley et al. 1986). However, feeding of Acartia spp. was not affected by any chemicals excreted from Luciella masanensis, which might have inhibited the feeding of $S$. jeokjo. Also, Acartia tonsa was reported to graze both non-toxic and potentially toxic strains of Pfiesteria piscicida at approximately equal rates (Roman et al. 2006). Therefore, with regard to Acartia spp., the effect of the toxicity of the chemicals excreted from L. masanensis or P. piscicida is likely to be less than that of toxic mixotrophic dinoflagellates.

\section{Growth and ingestion rates}

Heterotrophic dinoflagellates feed on bacteria (Lessard \& Swift 1985, Strom 1991, H. J. Jeong, K. A. Seong, T. H. Kim unpubl. data), algae (Jacobson 1987, Johnson et al. 2003, Menden-Deuer et al. 2005), heterotrophic nanoflagellates (Jeong et al. 2007b), ciliates (Burkholder \& Glasgow 1995), eggs and naupliar stages of copepods (Jeong 1994), larvae of bivalves (Burkholder \& Glasgow 1997, Springer et al. 2002), the blood of finfish (Burkholder \& Glasgow 1997, Parrow et al. 2005, Jeong et al. 2006), and the epidermis, muscle, and gills of finfish (Burkholder \& Glasgow 1997). However, prior to the present study, there had been no studies on the feeding by a heterotrophic dinoflagellate species on other heterotrophic dinoflagellate species. To enhance understanding of material cycling and energy flow in marine planktonic food webs, we should consider predator-prey relationships among heterotrophic dinoflagellates because usually several heterotrophic dinoflagellate species coexist (e.g. Jacobson 1987). The $\mu_{\max }$ of Oxyrrhis marina feeding on Pfiesteria piscicida $\left(0.66 \mathrm{~d}^{-1}\right.$; present study) is lower than that resulting from consumption of Heterosigma akashiwo (1.43 d $\mathrm{d}^{-1}$; Jeong et al. 2003), Amphidinium carterae (1.17 $\mathrm{d}^{-1}$; Jeong et al. 2001), and the diatom Phaeodactylum tricorutum $\left(1.30 \mathrm{~d}^{-1}\right.$; Goldman et al. 1989); however, it is comparable to that arising from predation on the phototrophic flagellates Dunaliella tertiolecta and Isochrysis galbana $\left(0.79 \mathrm{~d}^{-1}\right)$ or the raphidophyte Fibrocapsa japonica $\left(0.72 \mathrm{~d}^{-1}\right.$; Tillmann \& Reckermann 2002), when corrected to $20^{\circ} \mathrm{C}$ using $Q_{10}=2.8$ (Hansen et al. 1997). The $I_{\max }$ of $O$. marina feeding on $P$. piscicida (0.33 ng $C$ predator ${ }^{-1} \mathrm{~d}^{-1}$ ) is much lower than $I_{\max }$ values arising from consumption of all these algal prey species (1.3 to $7 \mathrm{ng} \mathrm{C}$ predator $^{-1}$ $\mathrm{d}^{-1}$ ). O. marina may have more difficulty and thus use more energy in capturing the heterotrophic dinoflagellate prey compared to the algal prey. However, P. piscicida as prey for O. marina may be more nutritional than the algal prey.

This is the first study on predation by Strombidinopsis spp. on Pfiesteria piscicida, Stockeria algicida, and Luciella masanensis. The $\mu_{\max }$ of Strombidinopsis jeokjo feeding on $P$. piscicida and $S$. algicida (1.61 to $1.77 \mathrm{~d}^{-1}$ ) was much higher than that resulting from the consumption of the heterotrophic dinoflagellates Gyrodinium dominans and Oxyrrhis marina prey $(0.54$ to $0.59 \mathrm{~d}^{-1}$; Jeong et al. 2004) and also clearly higher than that from feeding on the optimal algal prey Cochlodinium polykrikoides and Akashiwo sanguinea (1.41 to $1.53 \mathrm{~d}^{-1}$; Jeong et al. 1999), when corrected to $20^{\circ} \mathrm{C}$ using $Q_{10}=2.8$ (Hansen et al. 1997). The $\mu_{\max }$ in the present study is the highest observed value for $S$. jeokjo to date and thus $P$. piscicida and S. algicida are the optimal prey for culturing $S$. jeokjo. However, the $I_{\text {max }}$ of $S$. jeokjo feeding on $P$. piscicida and $S$. algicida ( 44 to 49 ng $C$ predator ${ }^{-1} \mathrm{~d}^{-1}$ ) in the present study was lower than that observed for $G$. dominans and $O$. marina as prey (87 to $106 \mathrm{ng} \mathrm{C}$ predator ${ }^{-1} \mathrm{~d}^{-1}$; Jeong et al. 2004) and much lower than that from feeding on the optimal algal prey (229 to $391 \mathrm{ng} \mathrm{C}$ predator $^{-1} \mathrm{~d}^{-1}$; Jeong et al. 1999), when corrected to $20^{\circ} \mathrm{C}$. These results suggest that (1) $P$. piscicida and $S$. algicida may sometimes comprise important prey for the growth of large Strombidinopsis species; and (2) P. piscicida and $S$. algicida are more nutritional as prey for $S$. jeokjo than G. dominans, O. marina, and algal prey. In natural environments, a higher abundance of $S$. jeokjo is expected when it co-occurs with $P$. piscicida and $S$. algicida compared to co-occurrence with $G$. dominans, O. marina, and algal prey.

The naked ciliates Euplotes spp., Strombidium spp., and Strobilidium sp. and the tintinnid ciliates Tintinnopsis spp., Tintinnidium spp., Nolaclusilis spp., and Favella sp. also feed on Pfiesteria piscicida (Stoecker et al. 2000, Lewitus et al. 2006). The maximum clearance rate of Strombidinopsis jeokjo feeding on $P$. piscicida (15 $\mu \mathrm{l}$ predator $^{-1} \mathrm{~h}^{-1}$ ) is comparable to that of Tintinnopsis spp. (4 to $19 \mu$ l predator ${ }^{-1} \mathrm{~h}^{-1}$ with an exception of $109 \mu$ predator ${ }^{-1} \mathrm{~h}^{-1}$ ) or Strombidium spp. (3 to $46 \mu \mathrm{l}$ predator ${ }^{-1} \mathrm{~h}^{-1}$; Stoecker et al. 2000, Setëlë et al. 2005), when corrected to $20^{\circ} \mathrm{C}$ using $Q_{10}=2.8$ (Hansen et al. 1997). Therefore, S. jeokjo may compete with these ciliates for $P$. piscicida prey in cases where they coexist. To enhance understanding of the interactions between dominant ciliates and $P$. piscicida, Stoeckeria algicida, and Luciella masanensis in marine environments, it is necessary to explore the numerical and functional responses of the ciliates to the prey concentration when fed on these 3 dinoflagellate prey. 
The calanoid copepod Acartia tonsa feeds on Pfiesteria piscicida (Mallin et al. 1995, Roman et al. 2006). The highest value (64 180 cells predator ${ }^{-1} \mathrm{~d}^{-1}$ ) among the ingestion rates of Acartia spp. (A. hongi and A. omorii) on $P$. piscicida at mean prey concentrations $<17500$ cells ml-1 is greater than rates for consumption of both non-toxic and toxic strains of $P$. piscicida (31920 and 29760 cells predator ${ }^{-1} \mathrm{~d}^{-1}$, respectively) (Roman et al. 2006). A. hongi or A. omorii are considerably longer than A. tonsa. This difference in size among Acartia species and variation in the $P$. piscicida strains ingested may be responsible for the difference in ingestion rates.

Only a few studies have reported on predation by copepods on Pfiesteria piscicida and other species belonging to the family Pfiesteriaceae. Thus, to enhance understanding of the interactions between these dinoflagellates and copepods in the natural environment, it would be worthwhile to investigate feeding by dominant copepods on $P$. piscicida and other dinoflagellate species.

Microzooplankton occasionally have considerable predation impact on the populations of Pfiesteria piscicida, and hence control the prey population; however, metazooplankton, including copepods, usually do not affect the prey populations (Stoecker \& Gustafson 2002, Roman et al. 2006). Nevertheless, it is very difficult to measure in situ ingestion rates of Oxyrrhis marina or Strombidinopsis jeokjo feeding on Stoeckeria algicida and/or Luciella masanensis or to calculate the predators' impact by combining the data on their ingestion rates and abundance because (1) differentiating among $P$. piscicida, S. algicida, and L. masanensis and then measuring their abundances in fixed natural samples remains difficult because advanced methods (such as DNA probes) of identifying $S$. algicida and $L$. masanensis have not been developed yet; (2) ingestion rates of $O$. marina or $S$. jeokjo feeding on each of $P$. piscicida, $S$. algicida, and L. masanensis differ greatly from those observed for consumption of the other prey species. Therefore, to enhance understanding of the interactions between P. piscicida, S. algicida, and $L$. masanensis and their predators at the population level, advanced methods for identifying these 3 dinoflagellates must be developed.

For a long time, species belonging to the family Pfiesteriaceae were probably not easily recognized due to their small size and the difficulty of establishing monoclonal cultures. However, recently, several new species in this family have been discovered (Jeong et al. 2005b, Litaker et al. 2005, Mason et al. 2007). The present study suggests that species in this family may have a distinct ecological niches and may be differentiated from each other based on their prey species, differential growth and ingestion rates (Lin et al. 2004,
Jeong et al. 2005a, 2006, 2007a) as well as the differential mortality rate due to predation as shown in the present study. Thus, to understand the roles of a newly discovered species in marine planktonic food webs, predator-prey relationships between the species and coexisting prey species, its growth and ingestion rates resulting from feeding on diverse prey, and the numerical and functional responses of the potential predators, in particular, heterotrophic protistans should be investigated simultaneously.

Acknowledgments. We thank S. T. Kim, K. A Seong, Y. D. Yoo, and M. S. Kim for technical support. This paper was funded by a Sookeuk grant from MOMAF \& KMI, a grant from the Korean Research Foundation (2005-070-C00143), and an NRL grant from MOST \& KOSEF (M1-0302-00-0068).

\section{LITERATURE CITED}

Burkholder JM, Glasgow HB Jr (1995) Interactions of a toxic estuarine dinoflagellate with microbial predators and prey. Arch Protistenkd 145:177-188

Burkholder JM, Glasgow HB Jr (1997) Trophic controls on stage transformations of a toxic ambush-predator dinoflagellate. J Eukaryot Microbiol 44:200-205

Frost BW (1972) Effects of size and concentration of food particles on the feeding behavior of the marine planktonic copepod Calanus pacificus. Limnol Oceanogr 17:805-815

Gifford DJ, Dagg MJ (1991) The microzooplankton-mesozooplankton link: consumption of planktonic protozoa by the calanoid copepods Acartia tonsa Dana and Neocalanus plumchrus Murukawa. Mar Microb Food Webs 5:161-177

Glasgow HB, Burkholder JM, Mallin MA, Deamer-Melia NJ, Reed RE (2001) Field ecology of toxic Pfiesteria complex species and a conservative analysis of their role in estuarine fish kills. Environ Health Perspect 109:715-730

Goldman JC, Dennett MR, Gordin H (1989) Dynamics of herbivorous grazing by the heterotrophic dinoflagellate Oxyrrhis marina. J Plankton Res 11:391-407

Gransden SG, Lewitus AJ (2003) Grazing of two euplotid ciliates on the heterotrophic dinoflagellates Pfiesteria piscicida and Cryptoperidiniopsis sp. Aquat Microb Ecol 33: 303-308

Hansen PJ, Bjornsen PK, Hansen BW (1997) Zooplankton grazing and growth: scaling within the $2-2,000-\mu \mathrm{m}$ body size range. Limnol Oceanogr 42:687-704

Heinbokel JF (1978) Studies on the functional role of tintinnids in the Southern California Bight. I. Grazing and growth rates in laboratory cultures. Mar Biol 47:177-189

Huntley M, Sykes P, Rohan S, Marin V (1986) Chemically-mediated rejection of dinoflagellate prey by the copepods Calanus pacificus and Paracalanus parvus: mechanism, occurrence and significance. Mar Ecol Prog Ser 28:105-120

Jacobson DM (1987) The ecology and feeding biology of thecate heterotrophic dinoflagellates. PhD thesis, Woods Hole Oceanographic Institution and Massachusetts Institute of Technology

Jeong HJ (1994) Predation by the heterotrophic dinoflagellate Protoperidinium cf. divergens on copepod eggs and early naupliar stages. Mar Ecol Prog Ser 114:203-208

Jeong HJ (1999) The ecological roles of heterotrophic dinoflagellates in marine planktonic community. J Eukaryot Microbiol 46:390-396 
Jeong HJ, Lee CW, Yih WH, Kim JS (1997) Fragilidium cf. mexicanum, a thecate mixotrophic dinoflagellate, which is prey for and a predator on co-occurring thecate heterotrophic dinoflagellate Protoperidinium cf. divergens. Mar Ecol Prog Ser 151:299-305

Jeong HJ, Shim JH, Lee CW, Kim JS, Koh SM (1999) Growth and grazing rates of the marine planktonic ciliate Strombidinopsis sp. on red-tide and toxic dinoflagellates. J Eukaryot Microbiol 46:69-76

Jeong HJ, Kang HJ, Shim JS, Park JY, Kim JS, Song JY, Choi HJ (2001) Interactions among the toxic dinoflagellate Amphidinium carterae, the heterotrophic dinoflagellate Oxyrrhis marina, and the calanoid copepods Acartia spp.. Mar Ecol Prog Ser 218:77-86

Jeong HJ, Kim JS, Yoo YD, Kim ST and 6 others (2003) Feeding by the heterotrophic dinoflagellate Oxyrrhis marina on the red-tide raphidophyte Heterosigma akashiwo: a potential biological method to control red tides using mass-cultured grazers. J Eukaryot Microbiol 50:274-282

Jeong HJ, Yoo YD, Kim JS, Kang NS, Kim TH, Kim JH (2004) Feeding by the marine planktonic ciliate Strombidinopsis jeokjo on common heterotrophic dinoflagellates. Aquat Microb Ecol 36:181-187

Jeong HJ, Kim JS, Kim JH, Kim ST, Seong KA, Kim TH, Song JY, Kim SK (2005a) Feeding and grazing impact of the newly described heterotrophic dinoflagellate Stoeckeria algicida on the harmful alga Heterosigma akashiwo. Mar Ecol Prog Ser 295:69-78

Jeong HJ, Kim JS, Park JY, Kim JH and 5 others (2005b) Stoeckeria algicida n. gen., n. sp. (Dinophyceae) from the coastal waters off southern Korea: morphology and small subunit ribosomal DNA gene sequence. J Eukaryot Microbiol 52:382-390

Jeong HJ, Ha JH, Park JY, Kim JH and 5 others (2006) Distribution of the heterotrophic dinoflagellate Pfiesteria piscicida in Korean waters and its consumption of mixotrophic dinoflagellates, raphidophytes, and fish blood cells. Aquat Microb Ecol 44:263-278

Jeong HJ, Ha JH, Yoo YD, Park JY and 5 others (2007a) Feeding by the Pfiesteria-like heterotrophic dinoflagellate Luciella masanensis. J Eukaryot Microbiol 54:231-241

Jeong HJ, Song JE, Kang NS, Kim S, Yoo YD, Park JY (2007b) Feeding by heterotrophic dinoflagellates on the common marine heterotrophic nanoflagellate Cafeteria sp. Mar Ecol Prog Ser 333:151-160

Johnson MD, Rome M, Stoecker DK (2003) Microzooplankton grazing on Prorocentrum minimum and Karlodinium micrum in Chesapeake Bay. Limnol Oceanogr 48:238-248

Kamiyama T, Arima S (2001) Feeding characteristics of two tintinnid ciliate species on phytoplankton including harmful species: effects of prey size on ingestion rates and selectivity. J Exp Mar Biol Ecol 257:281-296

Kim JS, Jeong HJ (2004) Feeding by the heterotrophic dinoflagellates Gyrodinium dominans and G. spirale on the red-tide dinoflagellate Prorocentrum minimum. Mar Ecol Prog Ser 280:85-94

Kimmel DG, Roman MR (2004) Long-term trends in mesozooplankton abundance in Chesapeake Bay, USA: influence of freshwater input. Mar Ecol Prog Ser 267:71-83

Lessard EJ (1991) The trophical role of heterotrophic dinoflagellates in diverse marine environments. Mar Microb Food Webs 5:49-58

Lessard EJ, Swift E (1985) Species-specific grazing rates of heterotrophic dinoflagellates in oceanic waters, measured with a dual-label radioisotope technique. Mar Biol 87: 289-296

Lewitus AJ, Hayes KC, Willis BM, Burkholder JM and 5 oth- ers (2002) Low abundance of the dinoflagellates, Pfiesteria piscicida, P. shumwayae, and Cryptoperidiniopsis spp., in south Carolina tidal creeks and open estuaries. Estuaries 25:586-597

Lewitus AJ, Wetz MS, Willis BM, Burkholder JM, Parrow MW, Glasgow HB (2006) Grazing activity of Pfiesteria piscicida (Dinophyceae) and susceptibility to ciliate predation vary with toxicity status. Harmful Algae 5:427-434

Lin S, Mulholland MR, Zhang H, Feinstein TN, Jochem FJ, Carpenter EJ (2004) Intense grazing and prey-dependent growth of Pfiesteria piscicida (Dinophyceae). J Phycol 40: 1062-1073

Litaker WR, Steidinger KA, Mason PL, Landsberg JH and 7 others (2005) The reclassification of Pfiesteria shumwayae (Dinophyceae): Pseudopfiesteria, gen. nov. J Phycol 41: 643-651

Mallin MA, Burkholder JM, Larsen LM, Glasgow HB Jr (1995) Response of two zooplankton grazers to an ichthyotoxic estuarine dinoflagellate. J Plankton Res 17:351-363

Marshall HG, Hargraves PE, Burkholder JM, Parrow MW and 10 others (2006) Taxonomy of Pfiesteria (Dinophyceae). Harmful Algae 5:481-496

Mason PL, Litaker RW, Jeong HJ, Ha JH and 9 others (2007) Description of a new genus of Pfiesteria-like dinoflagellate, Luciella gen. nov. (dinophyceae), including two new species: Luciella masanensis sp. nov. and Luciella atlantis sp. nov. J Phycol 43:799-810

Menden-Deuer S, Lessard E (2000) Carbon to volume relationships for dinoflagellates, diatoms, and other protist plankton. Limnol Oceanogr 45:569-579

Menden-Deuer S, Lessard EJ, Satterberg J, Grünbaum D (2005) Growth rates and starvation survival of three species of the pallium-feeding thecate dinoflagellate genus Protoperidinium. Aquat Microb Ecol 41:145-152

Moeller PDR, Beauchesne KR, Huncik KM, Davis WC, Christopher SJ, Riggs-Gelasco P, Gelasco AK (2007) Metal complexes and free radical toxins produced by Pfiesteria piscicida. Environ Sci Technol 41:1166-1172

Montagnes DJS, Berger JD, Taylor FJR (1996) Growth rate of the marine planktonic ciliate Strombidinopsis cheshiri Snyder and Ohman as a function of food concentration and interclonal variability. J Exp Mar Biol Ecol 206: 121-132

Noga EJ, Khoo L, Stevens JB, Fan Z, Burkholder JM (1996) Novel toxic dinoflagellate causes epidemic disease in estuarine fish. Mar Pollut Bull 32:219-224

Parrow MW, Glasgow HB, Burkholder JM, Zhang C (2002) Comparative response to algal prey by Pfiesteria piscicida, $P$. shumwayae and a co-occurring 'lookalike' species. In: Hallegraeff GM, Blackburn S, Bolch C, Lewis R (eds) Proc 9th Int Conf Algal Blooms. Intergovernmental Oceanographic Commission of UNESCO, Paris, p 101-104

Parrow MW, Burkholder JAM, Deamer NJ, Ramsdell JS (2005) Contaminant-free cultivation of Pfiesteria shumwayae (Dinophyceae) on a fish cell line. Aquat Microb Ecol 39:97-105

Roman MR, Reaugh ML, Zhang X (2006) Ingestion of the dinoflagellate, Pfiesteria piscicida, by the calanoid copepod, Acartia tonsa. Harmful Algae 5:435-441

Rublee RA, Remington DL, Schaefer EF, Marshall MM (2005) Detection of the Dinozoans Pfiesteria piscicida and $P$. shumwayae: a review of detection methods and geographic distribution. J Eukaryot Microbiol 52:83-89

Schmechel DE, Koltai DC (2001) Potential human health effects associated with laboratory exposures to Pfiesteria piscicida. Environ Health Perspect 109:775-779

Seaborn D, Dunstan W, Marshall H, Gordon A, Seaborn M 
(2002) Growth and toxicity studies of the dinoflagellates 'Cryptoperidiniopsis' sp., Gyrodinium galatheanum, and Pfiesteria piscicida. In: Hallegraeff GM, Blackburn S, Bolch C, Lewis R (eds) Proc 9th Int Conf Harmful Algal Blooms. Intergovernmental Oceanographic Commission of UNESCO, Paris, p 92-96

Setëlë O, Autio R, Kuosa H (2005) Predator-prey interactions between a planktonic ciliate Strombidium sp. (Ciliophora, Oligotrichida) and the dinoflagellate Pfiesteria piscicida (Dinamoebiales, Pyrrophyta). Harmful Algae 4:235-247

Sherr EB, Sherr BF (2002) Significance of predation by protists in aquatic microbial food webs. Antonie Leeuwenhoek 81:293-308

Shumway SE, Burkholder JM, Springer J (2006) Effects of the estuarine dinoflagellate Pfiesteria shumwayae (Dinophyceae) on survival and grazing activity of several shellfish species. Harmful Algae 5:442-458

Soh HY, Suh HL (2000) A new species of Acartia (Copepoda, Calanoida) from the Yellow Sea. J Plankton Res 22: 321-337

Springer JJ, Shumway SE, Burkholder JAM, Glasgow HB (2002) Interactions between the toxic estuarine dinoflagellate Pfiesteria piscicida and two species of bivalve molluscs. Mar Ecol Prog Ser 245:1-10

Steidinger KA, Burkholder JM, Glasgow HB Jr, Hobbs CW, Garrett JK, Truby EW, Noga EJ, Smith SA (1996) Pfiesteria piscicida gen. et sp. nov. (Pfiesteriaceae fam. nov.), a new toxic dinoflagellate with a complex life cycle and

Editorial responsibility: Barry \& Evelyn Sherr (Contributing Editors), Corvallis, Oregon, USA behavior. J Phycol 32:157-164

Steidinger KA, Landsberg J, Mason P, Vogelbein WK, Tester PA, Litaker W (2006) Cryptoperidiniopsis brodyi gen. et sp. nov. (Dinopgyceae), a small lightly armored dinoflagellate in the Pfiesteriaceae. J Phycol 42:951-961

Stoecker DK, Gustafson DE (2002) Predicting grazing mortality of an estuarine dinoflagellate, Pfiesteria piscicida. Mar Ecol Prog Ser 233:31-38

Stoecker DK, Stevens K, Gustafson DE Jr (2000) Grazing on Pfiesteria piscicida by microzooplankton. Aquat Microb Ecol 22:261-270

Strom SL (1991) Growth and grazing rates of the herbivorous dinoflagellate Gymnodinium sp. from the open subarctic Pacific Ocean. Mar Ecol Prog Ser 78:103-113

Tillmann U, Reckermann M (2002) Dinoflagellate grazing on the raphidophyte Fibrocapsa japonica. Aquat Microb Ecol 26:247-257

Turner JT, Doucette GJ, Keafer BA, Anderson DM (2005) Trophic accumulation of PSP toxins in zooplankton during Alexandrium fundyense blooms in Casco Bay, Gulf of Maine, April-June 1998. II. Zooplankton abundance and size-fractionated community composition. Deep-Sea Res Pt II 52:2784-2800

Verity PG, Wassmann P, Ratkova TN, Andreassen IJ, Nordby E (1999) Seasonal patterns in composition and biomass of autotrophic and heterotrophic nano- and microplankton communities on the north Norwegian shelf. Sarsia 84: 265-277

Submitted: January 5, 2007; Accepted: June 8, 2007 Proofs received from author(s): October 17, 2007 